\title{
Sugarcane starch: quantitative determination and characterization
}

\author{
Amido de cana-de-açúcar: determinação quantitativa e caracterização
}

\author{
Joelise de Alencar FIGUEIRA ${ }^{1 *}$, Priscila Hoffmann CARVALHO ${ }^{1}$, Hélia Harumi SATO ${ }^{1}$
}

\begin{abstract}
Starch is found in sugarcane as a storage polysaccharide. Starch concentrations vary widely depending on the country, variety, developmental stage, and growth conditions. The purpose of this study was to determine the starch content in different varieties of sugarcane, between May and November 2007, and some characteristics of sugarcane starch such as structure and granules size; gelatinization temperature; starch solution filterability; and susceptibility to glucoamylase, pullulanase, and commercial bacterial and fungal a-amylase enzymes. Susceptibility to debranching amylolytic isoamylase enzyme from Flavobacterium sp. was also tested. Sugarcane starch had spherical shape with a diameter of 1-3 $\mu \mathrm{m}$. Sugarcane starch formed complexes with iodine, which showed greater absorption in the range of 540 to $620 \mathrm{~nm}$. Sugarcane starch showed higher susceptibility to glucoamylase compared to that of waxy maize, cassava, and potato starch. Sugarcane starch also showed susceptibility to debranching amylolytic pullulanases similar to that of waxy rice starch. It also showed susceptibility to $a$-amylase from Bacillus subtilis, Bacillus licheniformis, and Aspergillus oryzae similar to that of the other tested starches producing glucose, maltose, maltotriose, maltotetraose, maltopentose and limit $\alpha$ - dextrin.
\end{abstract}

Keywords: sugarcane; starch; amylase.

\section{Resumo}

O amido é encontrado na cana-de-açúcar como um polissacarídeo de reserva. A quantidade depende de diversos fatores. Este trabalho visou a determinação do conteúdo de amido em diferentes variedades de cana-de-açúcar durante o período de Maio a Novembro de 2007; e determinação de algumas características do amido de cana-de-açúcar como: estrutura e tamanho dos grânulos de amido; determinação da temperatura de gelificação; determinação da filtrabilidade da solução de amido de cana-de-açúcar; susceptibilidade do amido de cana-de-açúcar às enzimas glicoamilase, pululanase, -amilases bacterianas e fúngica comerciais. Foi testado também a susceptibilidade do amido de canade-açúcar à enzima amilolítica desramificante isoamilase de Flavobacterium sp. O amido de cana-de-açúcar apresentou forma esférica e diâmetro entre 1-3 $\mu \mathrm{m}$. O amido de cana-de-açúcar complexado com iodo apresentou maior absorção na faixa de 540 a $620 \mathrm{~nm}$. O amido de cana-de-açúcar in natura mostrou maior susceptibilidade à enzima glicoamilase em relação aos outros amidos testados. O amido de canade-açúcar mostrou susceptibilidade à enzima amilolítica desramificante pululanase de modo similar ao amido de arroz ceroso. O amido de cana-de-açúcar mostrou susceptibilidade às a-amilases de Bacillus subtilis, Bacillus licheniformis e Aspergillus oryzae de modo similar aos outros amidos testados produzindo glicose; maltose; maltotriose; maltotetraose e $\alpha$ - dextrinas limite.

Palavras-chave: cana-de-açúcar; amido; amilase.

\section{Introduction}

Starch is a primary product of photosynthesis, and it is also temporarily stored in the sugarcane leaves as reserve food and may be converted into sugar (BOYES, 1958). Starch is found in sugarcane stalks, but it is more abundant in the leaves and growing point regions. Starch is found in all sugarcane products including raw and refined sugar and in sugarcane mills and refineries although its concentration varies greatly depending on the season, variety, sugarcane diseases, maturity, processing conditions, and analysis method (IMRIE; TILBURY, 1972).

Several studies have shown that the presence of polysaccharides contributes to loss and inefficient production in sugar mills. The starch and dextran present in sugarcane juice interfere in the clarification, filtration, and crystallization processes. During processing, they increase viscosity, inhibit crystallization, and increase the loss of sucrose to molasses. They may also contribute to polarization distortions. It is known that polysaccharides such as starch are not completely extracted during processing, and that they end up being incorporated into raw crystal sugar. Studies have shown that 200-250 ppm starch level in raw sugar refinery may cause problems during processing (CUDDIHY; PORRO; RAUH, 2006).

The aim of this work was to quantitatively determine sugarcane starch in five varieties of sugarcane (RB86-7515, SP83-2847, RB72-454, SP80-3280 and RB85-5536) during harvest (May to November 2007) and study some of the characteristics of the sugarcane starch.

Received 10/3/2010

Accepted 9/7/2010 (004724)

${ }^{1}$ Laboratory of Food Biochemistry, Department of Food Science, School of Food Engineering, University of Campinas - UNICAMP, Rua Monteiro Lobato, 80, CP 6121, CEP 13083-862, Campinas, SP, Brazil, e-mail: joaf@fea.unicamp.br

${ }^{*}$ Corresponding author 


\section{Materials and methods}

\subsection{Starch determination in sugarcane juice}

Juice samples of varieties RB86-7515, SO83-2847, RB72-454, SP80-3280, and RB85-5536 were collected every 15 days in a sugar mill located in the region of Santa Bárbara D'Oeste - SP (Brazil). The starch concentration in sugarcane juice was determined by the official method applied in the Australian sugar industry (2001) and utilized by the Copersucar's Canavieira Technology Center. Potato starch is the standard methodology. Starch extracted from sugarcane juice was also tested for comparison. A statistical analysis was performed with the Minitab version 14 software through Tukey's test with $95 \%$ significance.

Average temperatures and pluviometric indexes from May to December 2007 in the region of Santa Bárbara D’oeste were obtained at the Agricultural, Meteorological, and Climatic Research Center (CEPAGRI) site.

\subsection{Sugarcane juice starch extraction and purification}

The sugarcane juice starch was extracted as described by Park, Martens and Sato (1985). 2 L sugarcane juice sample were filtered through cloth and then centrifuged at $9.630 \times \mathrm{g}$ for 15 minutes at $5{ }^{\circ} \mathrm{C}$. The precipitate was washed with distilled water several times. The starch suspension in water was treated with the same volume of chloroform in a separating funnel several times to remove colored compounds as described by Stevenson and Whayman (1976).

\subsection{Sugarcane starch granule structure}

The sugarcane starch granule structure was observed in a scanning electron microscope (JEOL model JSM 5800 LV). The extracted starch granules were spread on a double-sided adhesive tape for gold fixation and deposition in a sputter coater (Balzer model SCP 050). Potato, maize, and cassava commercial starch samples were utilized for comparison.

\subsection{Starch-iodine complex absorption spectrum}

The absorption spectrum profile of sugarcane starch, waxy maize starch, maize starch, soluble potato starch, potato starch, and 99\% amylopectin-iodine complex solutions were determined by a Beckman Coulter DU 640 spectrophotometer in a 380 to $700 \mathrm{~nm}$ range according to the method described by Archibald et al. (1988) with modifications.

\subsection{Determination of sugarcane starch gelatinization temperature}

The gelatinization temperature of sugarcane starch was determined as described by Park, Martens and Sato (1985). Test tubes containing $10 \mathrm{~mL}$ of starch-water suspension (1\%) were incubated at $50-80{ }^{\circ} \mathrm{C}$. The test tubes were removed from the water-baths at five minute-intervals and examined for swelling and gelatinization of the starch under a microscope.

\subsection{Determination of the sugarcane starch solution filterability}

In the filterability study, $0.02 \%$ sugarcane starch and potato starch suspensions were gelatinized. The gelatinized starch samples were filtered in $0.2 \mu \mathrm{m}, 0.8 \mu \mathrm{m}$ and $5 \mu \mathrm{m}$ porosity membranes using Büchner flasks and vacuum. To verify the presence of starch in the membranes and filtered solution samples, a 0.01 iodine-KI solution was utilized.

\subsection{Sugarcane starch susceptibility to different amylolytic enzymes}

\section{Sugarcane starch susceptibility to glucoamylase enzyme}

The sugarcane starch susceptibility to glucoamylase enzyme (AMG 300L -Novozymes) was tested using natural and gelatinized starch as described by Sato (1991). Test tubes containing $1 \mathrm{~g}$ natural and $0,1 \mathrm{~g}$ gelatinized starch, $30 \mu \mathrm{L}$ of commercial enzyme and $30 \mu \mathrm{L}$ of distillated water were incubated at $50^{\circ} \mathrm{C}$ for 1 hour. The test tubes were removed from the water-baths, and reducing sugars were determined by the Somogyi-Nelson method (1945) using glucose as standard. The absorbance of the samples was determined at $540 \mathrm{~nm}$.

\section{Sugarcane starch susceptibility to pullulanase enzyme}

The sugarcane starch susceptibility to pullulanase enzyme (Promozyme 400L - Novo Nordisk) was tested using cassava, potato, maize, waxy rice, and waxy maize starch for comparison as described by Sato (1991). Pullulanase activity in different varieties of starch was analyzed by iodine reagent coloration. The absorbance of the solutions was measured at $620 \mathrm{~nm}$. One unit of pullulanase activity was defined as an increment in absorbance at $620 \mathrm{~nm}$ of 0.01 per $\mathrm{mL}$ of the enzyme in one minute. Pullulanase activity was also analyzed though the determination of reducing sugars formed from the different starch hydrolysis. Reducing sugars were determined by the Somogyi-Nelson method (1945). One pullulanase unit was defined as an increment in the reducing sugars of $1 \mu \mathrm{mol}$ per $\mathrm{mL}$ of enzyme in one minute.

\section{Sugarcane starch susceptibility to isoamylase enzyme}

The hydrolysis of the sugarcane starch by debranching amylolytic isoamylase enzyme produced by the Flavobacterium sp. lineage was tested. Flavobacterium sp. maintained on nutrient agar slant containing $0.5 \%$ rice amylopectin (Merck) was inoculated in plates of nutrient agar containing $0.5 \%$ sugarcane starch in a line segment shape. Plates of nutrient agar containing $0.5 \%$ cassava, maize, waxy maize, or waxy rice starch were also prepared for comparison. After 24 to 48 hours of incubation at $25{ }^{\circ} \mathrm{C}$, a diluted iodine-KI solution was added to check the formation of a hydrolysis halo around the colony (SATO, 1979).

\subsection{Sugarcane starch susceptibility to commercial bacterial and fungal $\alpha$-amylase enzymes}

The enzymatic susceptibility of sugarcane starch was tested as described by Sato (1991) using commercial $\alpha$-amylase enzymes from Bacillus subtilis, Bacillus licheniformis (Termamyll 
120L - Novozymes) and Aspergillus oryzae (Fungamyll $800 \mathrm{~L}$ - Novozymes). The hydrolysis products were analyzed by descending paper chromatography using a butanol: piridine: distilled water (6:4:3 v:v:v) solvent system. Chromatogram development time was 48 hours for a $46 \mathrm{~cm}$ length paper tape. Reducing sugars were revealed with $\mathrm{AgNO}_{3}$ and alcoholic $\mathrm{NaOH}$ as described by Trevelyan, Procter and Harrison (1950). Potato, cassava, waxy maize, and waxy rice starch were used for comparison.

\section{Results and discussion}

\subsection{Starch determination in sugarcane juice}

The starch content of five varieties of sugarcane was determined in samples collected every 15 days from May 29 to November 6, 2007 using potato starch and sugarcane starch as standards. Table 1 illustrates the starch content of the sugarcane varieties determined by using potato starch and sugarcane starch for the preparation of the standard curve.

A statistical analysis was performed using the Minitab version 14 software through Tukey's test with $95 \%$ significance. No difference among sugarcane juice starch content values was determined for the sugarcane varieties with potato, and a sugarcane starch standard curve was verified. The statistical analysis was performed for each variety comparing the average values obtained with potato and sugarcane starch standard curves for each collection performed.

RB86-7515 and SO83-2847 sugarcane varieties showed respectively higher and lower average starch content (2581 mg.kg. $\%{ }^{\circ}$ Brix and $1658 \mathrm{mg} / \mathrm{kg} . \%{ }^{\circ}$ Brix), (potato starch standard curve), during the period of May to November 2007, among the sugarcane varieties studied.

Godshall et al. (1998) determined the total polysaccharide content and the starch content in 6 sugarcane varieties cultivated in the Louisiana (USA) region during the years of 1990, 1991, and 1992. CP72-370, CP79-318, LCP82-89, CP65-357, CP74-383 and CP70-321 sugarcane varieties presented, respectively, average starch content of $1021,602,603,612$, and $245 \mathrm{ppm}$ based on solids content .These values correspond to $\mathrm{mg} / \mathrm{kg} . \%{ }^{\circ}$ Brix.

According to Eggleston, Legendre and Tew (2004), starch content is higher in immature sugarcane than in mature sugarcane. The authors observed that there was a decrease in the starch content in all samples and sugar clarification systems throughout the crop, which they attributed to sugarcane's maturity increase.

Figure 1 illustrates starch contents in the different sugarcane varieties from May to November 2007, and Figure 2 illustrates temperature variation and rainfall index $(\mathrm{mm})$ from May to December 2007.

The months of June and July 2007 presented the lowest temperature values and pluviometric index. A correlation between the starch content in the five sugarcane varieties juice

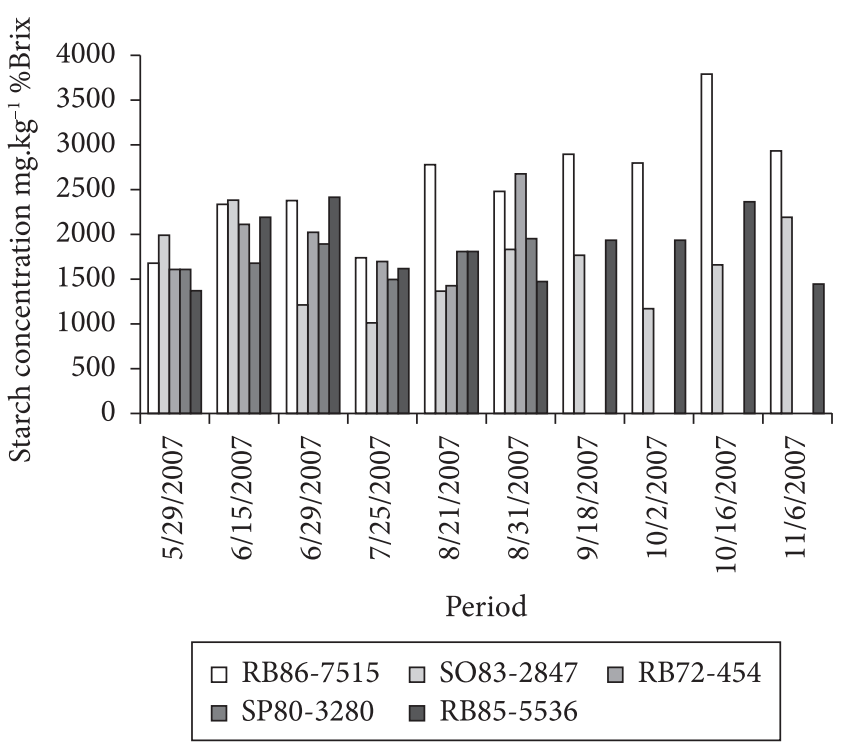

Figure 1. Starch content in the sugarcane varieties using standard curve.

Table 1. Starch content ${ }^{*}\left(\mathrm{mg} / \mathrm{kg} . \%{ }^{\circ}\right.$ Brix $)$ of the sugarcane varieties determined by using potato starch (PS) and sugarcane starch (SS) for the preparation of the standard curve

\begin{tabular}{|c|c|c|c|c|c|c|c|c|c|c|}
\hline \multirow[t]{2}{*}{ Date } & \multicolumn{2}{|c|}{ RB86-7515 } & \multicolumn{2}{|c|}{ SO83-2847 } & \multicolumn{2}{|c|}{ RB72-454 } & \multicolumn{2}{|c|}{ SP80-3280 } & \multicolumn{2}{|c|}{ RB85-5536 } \\
\hline & SS & PS & SS & PS & SS & PS & SS & PS & SS & PS \\
\hline $29 / 5 / 07$ & 1695 & 1678 & 2015 & 1991 & 1568 & 1552 & 1609 & 1593 & 1342 & 1330 \\
\hline $15 / 6 / 07$ & 2364 & 2334 & 2411 & 2381 & 2082 & 2059 & 1677 & 1660 & 2178 & 2150 \\
\hline $29 / 6 / 07$ & 2411 & 2378 & 1221 & 1213 & 2006 & 1982 & 1898 & 1875 & 2408 & 2376 \\
\hline $25 / 7 / 07$ & 1761 & 1741 & 1014 & 1009 & 1666 & 1648 & 1494 & 1479 & 1592 & 1575 \\
\hline $21 / 8 / 07$ & 2818 & 2779 & 1375 & 1364 & 1387 & 1375 & 1806 & 1785 & 1792 & 1772 \\
\hline $31 / 8 / 07$ & 2518 & 2482 & 1856 & 1834 & 2670 & 2633 & 1957 & 1931 & 1444 & 1429 \\
\hline 18/9/07 & 2940 & 2896 & 1791 & 1769 & - & - & - & - & 1913 & 1888 \\
\hline $2 / 10 / 07$ & 2843 & 2799 & 1181 & 1171 & - & - & - & - & 1519 & 1502 \\
\hline $16 / 10 / 07$ & 3853 & 3791 & 1678 & 1659 & - & - & - & - & 2347 & 2313 \\
\hline $6 / 11 / 07$ & 3073 & 2932 & 2245 & 2193 & - & - & - & - & 1440 & 1403 \\
\hline Mean & 2628 & 2581 & 1679 & 1658 & 1896 & 1875 & 1740 & 1721 & 1798 & 1774 \\
\hline
\end{tabular}

(*) Analysis in triplicate; ( ) samples not available in the period. 


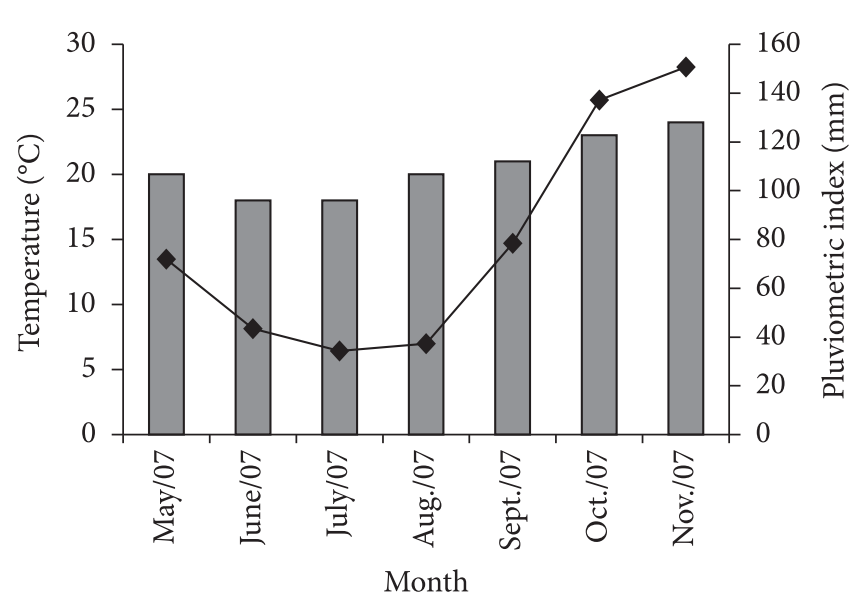

Figure 2. Temperature e Pluviometric Index in the region of Santa Bárbara D’Oeste from May to November 2007.

collected from March to November 2007 and the parameters temperature and pluviometric index was not observed.

According to Anyangwa, Kapseu and Musonge (1993), starch is a sugarcane natural polysaccharide, and its concentration depends on several factors such as growth conditions, plant's variety, cultivation soil, and harvest method.

Cuddihy, Porro and Rauh (2001) studied the starch content of four Australian sugarcane varieties and concluded that starch content is a characteristic of each variety. They observed that the sugarcane starch content did not vary significantly in the last three maturity months, but that the raw sugar produced at the beginning of the crop could have a high level of starch.

\subsection{Sugarcane starch granule structure}

Sugarcane starch granules are considerably smaller than those of potato, cassava, and maize starch. The potato, maize, and cassava starch granules presented a size of about $20-50 \mathrm{~m}$, 10-15 $\mu \mathrm{m}$ and 8-20 $\mu \mathrm{m}$, respectively. Figures 3 (a, b, c, and d) shows sugarcane, potato, cassava, and maize starch granules, respectively, viewed under an electron microscope (magnified 1000x).

The granules presented globular, oval, and semispherical shapes and a size of about 1-3 $\mu \mathrm{m}$. Kampen (2006) reported that sugarcane starch granules, presented a diameter of 1-10 $\mu \mathrm{m}$, whereas Stevenson and Whayman (1976) and Park, Martens and Sato (1985) verified a diameter of about 1-5 $\mu \mathrm{m}$. Figure 4 illustrates starch granules, respectively, viewed under an electron microscope (magnified 1000x).

\subsection{Starch and iodine complex absorption spectrum}

Figure 5 shows the absorption spectrum profile of waxy maize starch $\left(\lambda_{\max } 426\right)$, maize starch $\left(\lambda_{\max } 526\right)$, soluble potato starch $\left(\lambda_{\max } 553\right)$, potato starch $\left(\lambda_{\max } 565\right)$, starch with $99 \%$ amylopectin $\left(\lambda_{\max } 453\right)$, and sugarcane- starch iodine complex $\left(\lambda_{\max } 585\right)$.

The sugarcane starch -iodine complex presented a $\lambda$ for maximum absorption at $585 \mathrm{~nm}$, which is closer to the absorption values of complexes that usually present $75 \%$ amylopectin and 25\% amylose when compared with the absorption values of starch complexes that present higher amylopectin content, such as waxy maize starch $\left(\lambda_{\max } 426\right)$ and starch with $99 \%$ amylopectin $\left(\lambda_{\max } 453\right)$.

Vignes (1974) reported that sugarcane starch granules contain 19\% amylose and $81 \%$ amylopectin, while Kampen (2006) observed that they contain $20 \%$ and $80 \%$ amylopectin.

\subsection{Determination of the sugarcane starch gelatinization temperature}

The sugarcane starch granules were gelatinized in a temperature range of $70-75^{\circ} \mathrm{C}$. Park, Martens and Sato (1985) found that sugarcane starch gelatinized in a $65-80^{\circ} \mathrm{C}$ range, and reported that the gelatinization temperature was considerably higher than that of cassava starch, which presents gelatinization temperature in a 65 to $70{ }^{\circ} \mathrm{C}$ range. Maize, rice, and potato starch gelatinized in a 56 to $72^{\circ} \mathrm{C}, 80^{\circ} \mathrm{C}$, and 60 to $65^{\circ} \mathrm{C}$ range, respectively (ARIAS, 2000).

\subsection{Sugarcane starch solution filterability}

In the study of the $0.02 \%$ gelatinized sugarcane starch suspension filterability in the $0.2,0.8$ and $5.0 \mu \mathrm{m}$ porosity membranes, it was verified that both filtrates and retained substances presented a blue coloration with a $0.1 \mathrm{~N}$ iodine-KI solution, indicating the presence of lower than $0.2 \mu \mathrm{m}$ and higher than $5.0 \mu \mathrm{m}$ fractions.

The $0.02 \%$ gelatinized potato starch suspension also presented fractions smaller than $0.2 \mu \mathrm{m}$ and larger than $5.0 \mu \mathrm{m}$. The sugarcane starch may cause filterability problems in raw sugar solutions. According to Cuddihy, Porro and Rauh (2001), starch concentrations in raw sugar from 200 to $250 \mathrm{ppm}$ cause filtration problems during the processing.

The main factors that influence the filtration stage are usually pressure, time, filtration area, solution viscosity, and the characteristics of the solids to be filtered. In sugar refineries, filtration is performed to promote the removal of particulate material and sugar solution discoloration. It is also performed to obtain sugar solutions with the desired quality using few resources. Refineries in North America utilize silica and diatom filters to ensure clarification. Research has been carried to promote the adequacy and standardization of the filters used by sugar refineries. Filter-manufacturing companies and refineries are cooperating to produce more economic filters (CUMMINS; WEYMOUTH, 1942).

\subsection{Sugarcane starch susceptibility to different amylolytic enzymes}

Sugarcane starch susceptibility to glucoamylase enzyme

The sugarcane starch hydrolysis was tested with glucoamylase, bacterial $\alpha$-amylases, fungal $\alpha$-amylase, pullulanase, and isoamylase.

Natural sugarcane starch showed higher susceptibility to glucoamylase compared with that of waxy maize, cassava, and potato starch. Natural waxy rice starch presented the highest 

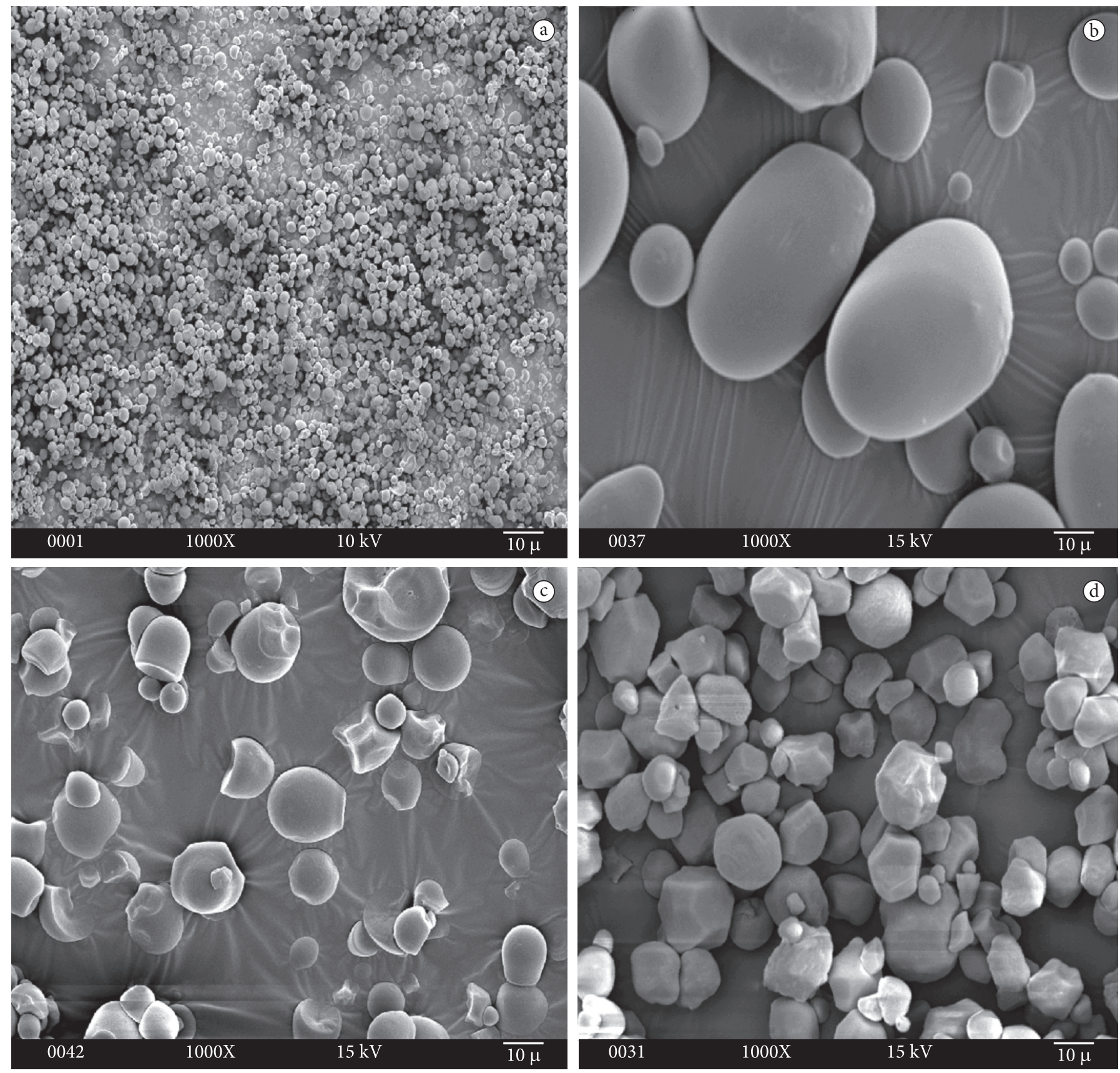

Figure 3. a) Sugarcane starch grains; b) potato starch; c) cassava starch; and d) maize starch 1000× magnification.

susceptibility to glucoamylase among all tested starches. Figure 6 illustrates the reducing sugar production from natural starch from different sources using glucoamylase.

Glucoamylase, also known as amyloglucosidadase, hydrolyzes the $\alpha-1,4, \alpha-1,6$ and $\alpha-1,3$ glycosidic bonds of starch and its by-products liberating glucose units. The commercial glucoamylase is used in the liquefied starch saccharification stage and glucose production (RÍAZ et al., 2007).

Glucoamylase of Aspergillus niger and Rhizopus sp. can hydrolyze gelatinized starch and also natural starch at a lower rate (WANKHEDE; RHATEKE, 1982).
The gelatinized sugarcane starch showed higher susceptibility to glucoamylase enzyme among all tested starches. Both natural and gelatinized potato starch presented the lowest susceptibility to glucoamylase among the tested starches. Figure 7 illustrates the reducing sugars production from gelatinized starch from different sources using glucoamylase.

It was observed that glucoamylase hydrolyzed the gelatinized starch samples with higher intensity than the natural starches indicating that the thermal treatment used for gelatinizing exposed the amylose and amylopectin chains facilitating enzyme activity. 


\section{Sugarcane starch susceptibility to the debranching amylolytic pullulanase enzyme}

The sugarcane starch hydrolysis and the hydrolysis of other types of starch by pullulanase were determined by the color formed with the iodine reagent and the determination of reducing sugars by the Somogyi-Nelson method (1945).

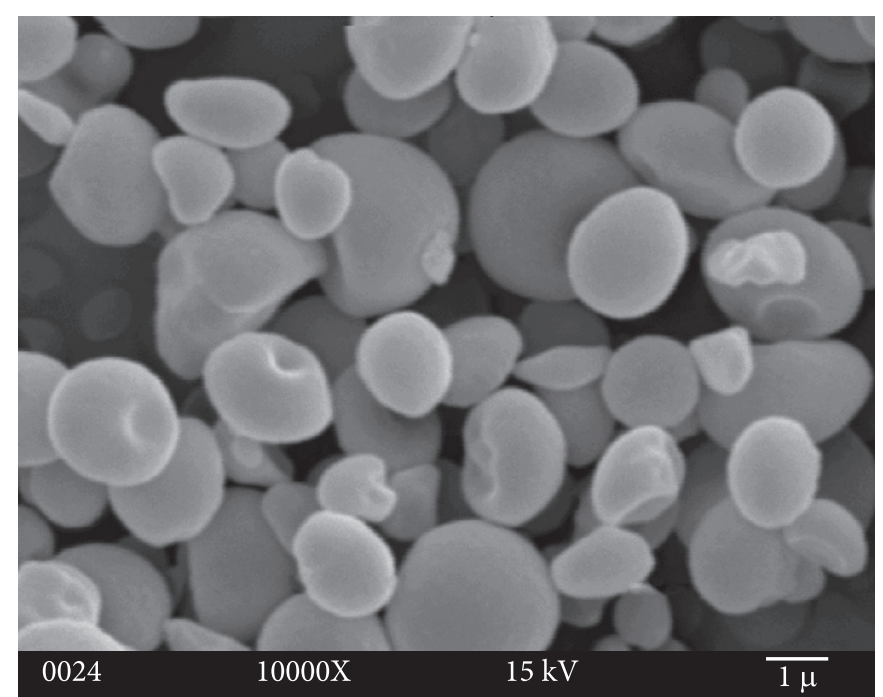

Figure 4. Sugarcane starch granules (10.000 x magnification).

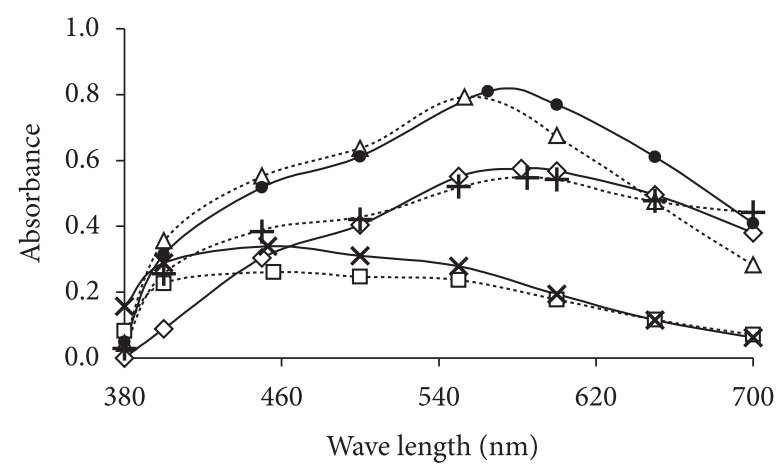

$$
\begin{aligned}
& \cdots \square \text {... Waxy corn } \frown \text { Corn } \quad \cdots \Delta \cdots \text { Soluble starch } \\
& \rightarrow \quad \text { Starch with } 99 \% \text { amylopectin } \cdots+\cdots \text { Sugarcane } \longrightarrow \text { Potato }
\end{aligned}
$$

Figure 5. Absorption profile of starch-iodine complexes.

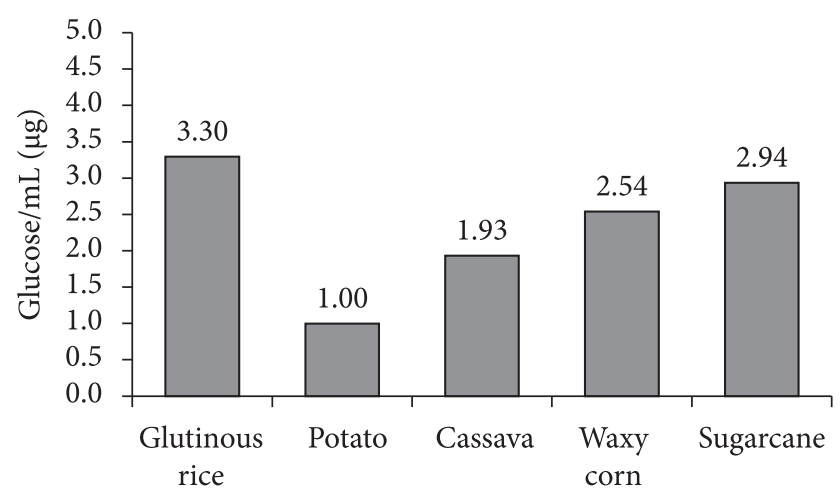

Figure 6. Hydrolysis of different in nature starch by glucoamylase enzyme at $50^{\circ} \mathrm{C}$ for 1 hour.
Figure 8 shows that in the study of the susceptibility to the debranching amylolytic pullulanase enzyme, analyzed by the color formed with the iodine reagent, the sugarcane starch showed a similar susceptibility to the waxy rice starch, which present a high amylopectin content. Potato starch presented the lowest susceptibility to pullulanase among all tested starches.

In the study of the susceptibility to the debranching amylolytic pullulanase enzyme, analyzed by the determination of the reducing sugars produced, sugarcane starch presented susceptibility similar to that of waxy maize starch, which contains high amylopectin content, as seen in Figure 9.

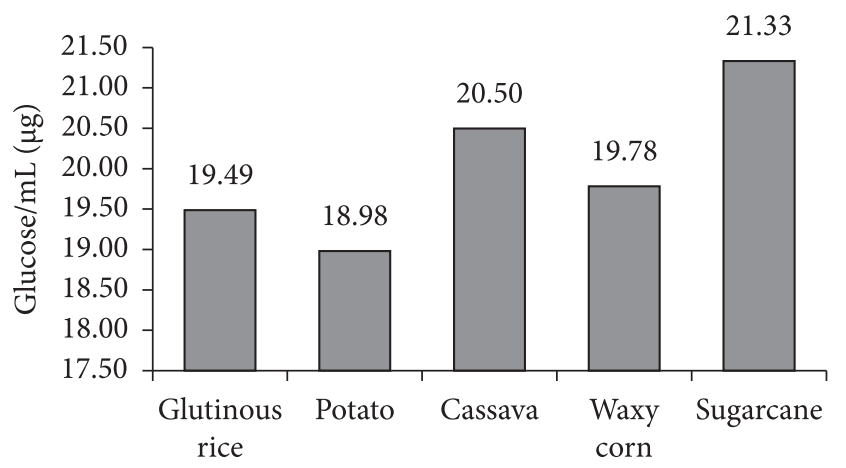

Figure 7. Hydrolysis of different frozen starch by glucoamylase enzyme.

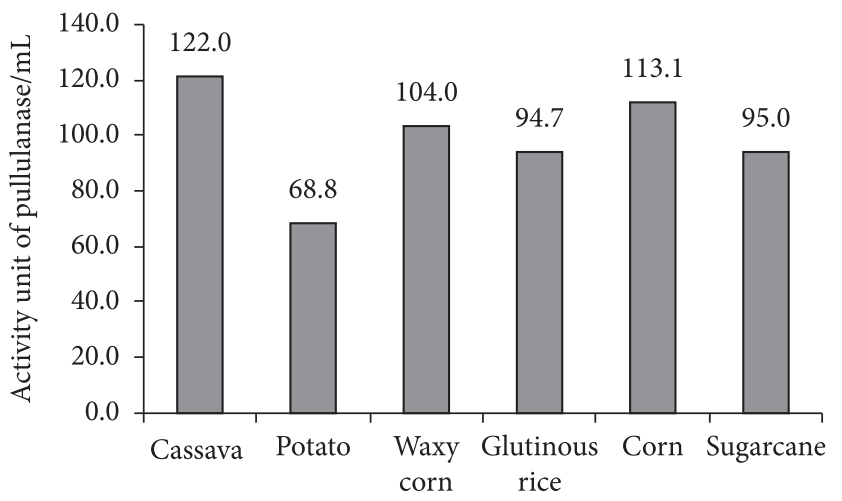

Figure 8. Hydrolysis of different types of starch by the branch cleavage promoting amylolytic pullulanase enzyme determined by the coloration test with iodine reagent.

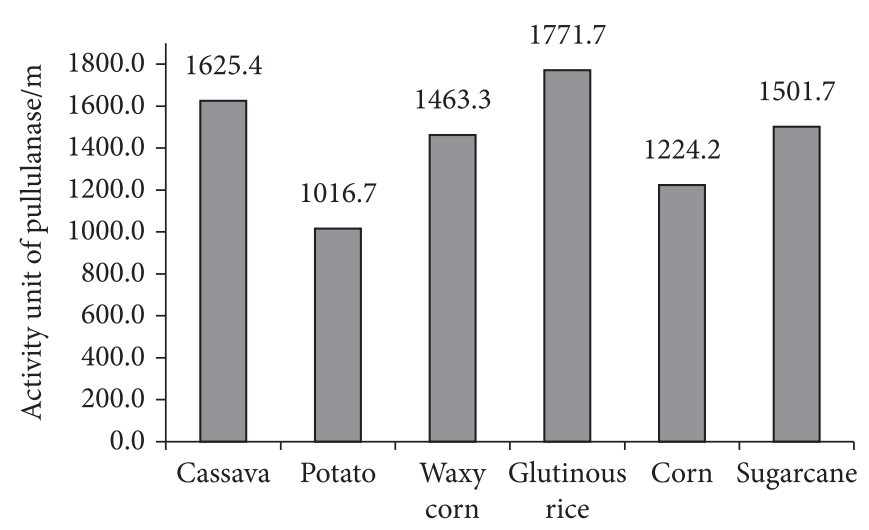

Figure 9. Hydrolysis of different types of starch by the branch cleavage promoting amylolytic pullulanase enzyme determined by reducing sugars formation. 
The pullulanase is an enzyme that hydrolyzes specifically the $\alpha-1,6$ glycosidic bonds of starch and its by-products that contain at least two glucose units in the lateral branched chains (ABDULLAH; FRENCH, 1970).

Whayman and Willesdorf (1976) reported that N:Co310 and Q58 sugarcane starch varieties presented 15\% amylose, while potato starch contained $23 \%$ amylose. The authors suggested that the sugarcane amylopectin was less branched than that of maize or potato starch amylopectin.

Sugarcane starch susceptibility to the debranching amylolytic isoamylase enzyme

The nutrient agar plate containing $0.5 \%$ sugarcane starch (Figure 10a) presented blue bottom coloration indicating that starch contains amylose. It was observed that the microorganism Flavobacterium sp. produced extracellular isoamylase, which hydrolyzed amylopectin liberating linear amylose chains and intensifying the blue coloration around the colony (Figure 10a).

Figures $10 \mathrm{~b}$ and $10 \mathrm{c}$ show that the culture medium containing cassava and maize starch presented blue bottom coloration indicating the presence of amylose. Cassava and maize starch contain, respectively, $17 \%$ amylose $+83 \%$ amylopectin and $28 \%$ amylose $+72 \%$ amylopectin (BEMILLER; WHISTLER, 1996).
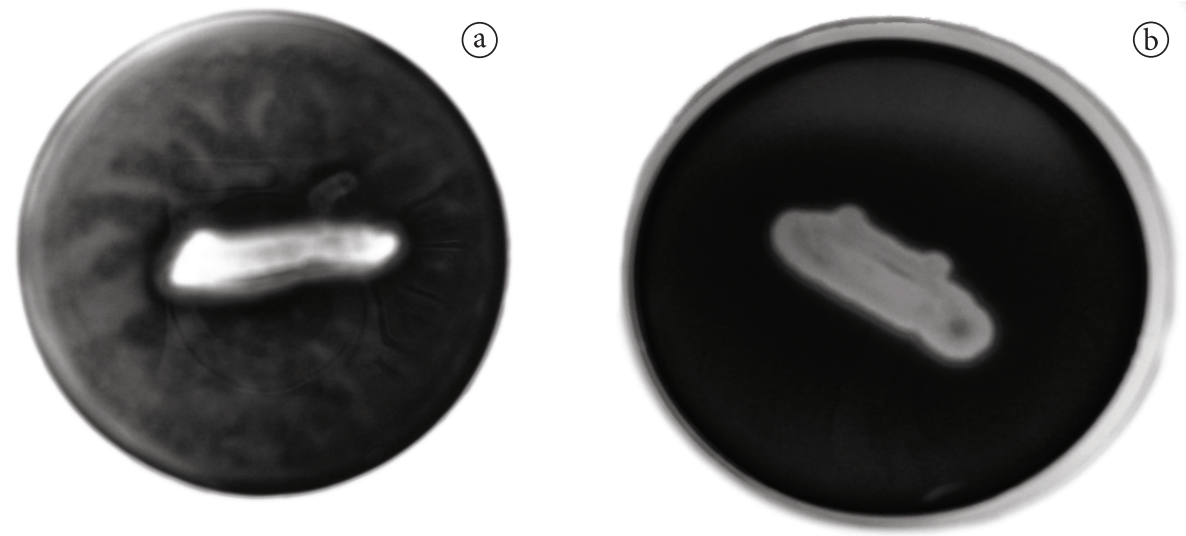

(b)
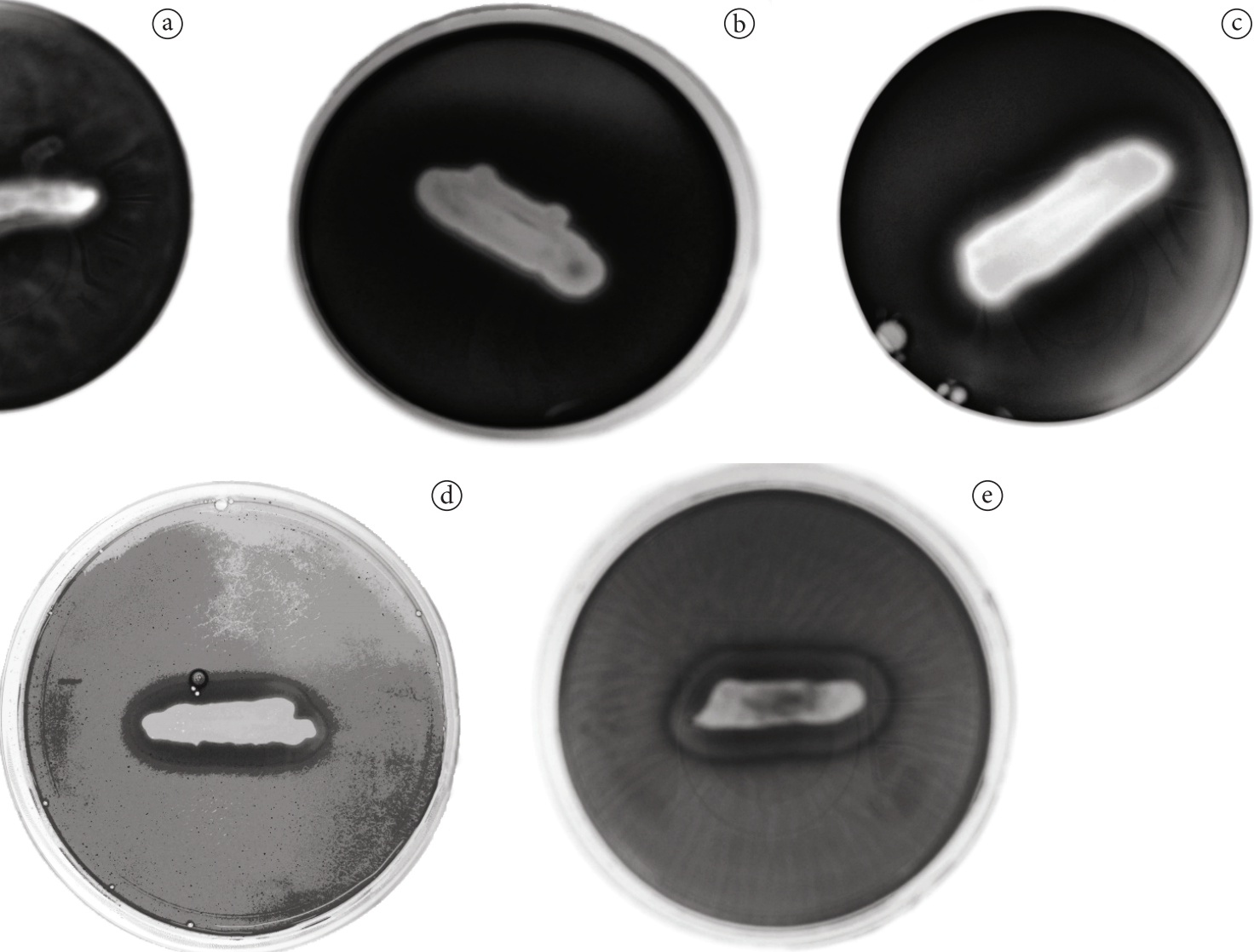

(d)

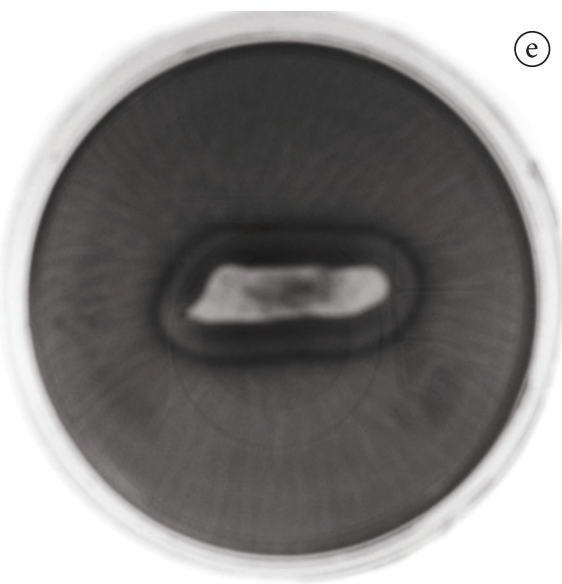

Figure 11 illustrates the reducing sugars produced in the waxy rice, potato, cassava, waxy maize and sugarcane starch hydrolysis by amylase Termamyl, obtained from Bacillus licheniformis. In the sugarcane starch hydrolysis, the formation of glucose, maltose, maltotriose, and maltotetraose isoamylase, which hydrolyzed the amylopectin fraction of maize and cassava starch (Figure 10b and Figure 10c) liberating linear amylose chains and intensifying the blue coloration around the colony.

Figures $10 \mathrm{~d}$ and $10 \mathrm{e}$ illustrate that waxy rice and waxy maize starch contain high amylopectin content by presenting reddish bottom coloration with an iodine-KI solution, and that the isoamylase production by microorganism Flavobacterium sp. resulted in the hydrolysis of amylopectin and liberation of linear amylose chains that presented a blue coloration with iodine.

Isoamylase from Flavobacterium sp. preferably hydrolyzes amylopectin $\alpha-1,6$ glycosidic bonds that involve long linear chains. This indicates that sugarcane starch contains the branched amylopectin fraction that can be hydrolyzed by isoamylase.

\subsection{Sugarcane starch susceptibility to the commercial acterial and fungal $\alpha$-amylase}


was observed. The sugarcane starch showed susceptibility to the $\alpha$-amylase from B. subtilis similarly to that of the other tested starches.

The a-amylase from Bacillus licheniformis hydrolyzes starch $\alpha-1,4$ glycosidic bonds randomly by reducing the viscosity and coloration capacity of starch and its by-products with iodine reagent. The $\alpha$-amylase from $B$. licheniformis is a thermostable enzyme utilized in tarch liquefaction and maltodextrin production.

In sugarcane starch hydrolysis by the $a$-amylase from Bacillus subtilis, the formation of glucose, maltose, maltotriose, maltotetraose, and other greater molecular weight oligosaccharides was observed. The sugarcane starch showed susceptibility to $a$-amylase from $B$. subtilis similar to that of the other tested starches. Figure 12 illustrates the reducing sugars produced after the waxy rice, potato, cassava, waxy maize, and sugarcane starch hydrolysis by $a$-amylase from $B$. subtilis.

The a-amylase from Bacillus subtilis hydrolyzes the $\alpha-1,4$ glycosidic bonds of the starch reducing its viscosity and coloration capacity with iodine reagent.

The a-amylase from Bacillus subtilis is less thermostable than the a-amylase from B. licheniformis, and it is used in the starch liquefaction and the maltodextrin production.

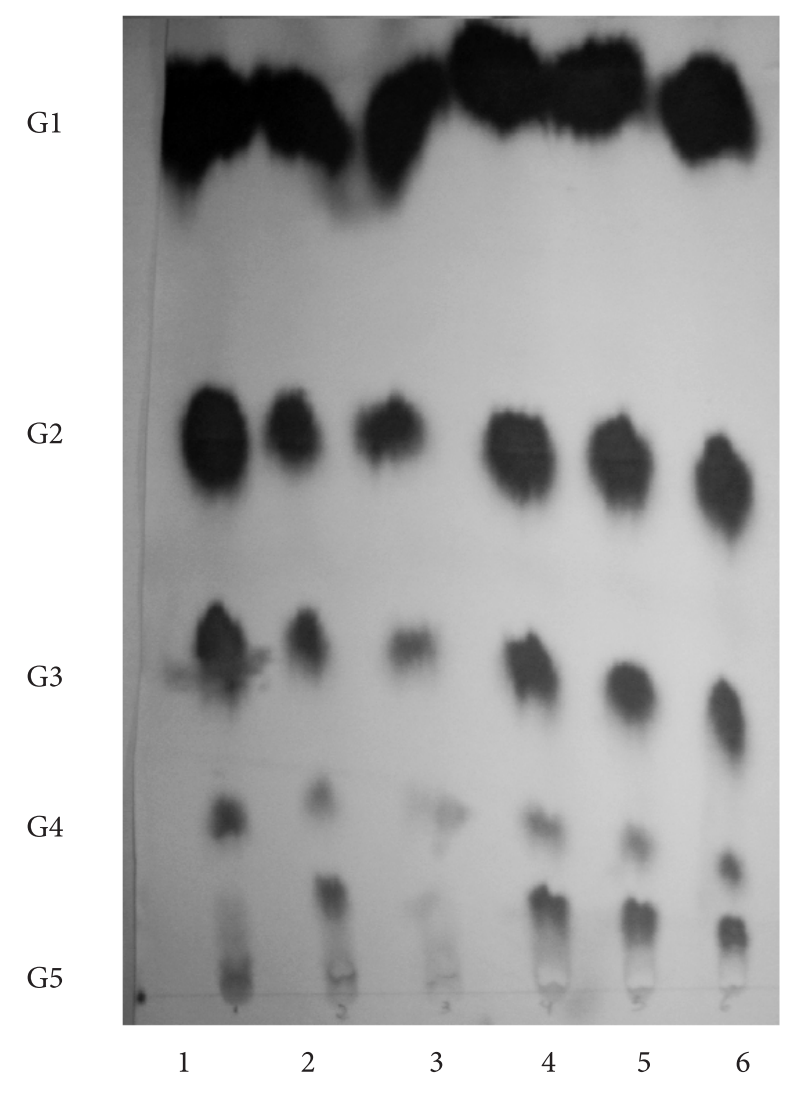

Figure 11. Reducing sugars formed after waxy rice, potato, cassava, waxy maize and sugarcane starch hydrolysis by a-amylase from Bacillus licheniformis.
Park, Martens and Sato (1985) verified that natural sugarcane starch is susceptible to bacterial and fungal $\alpha$-amylase, but the hydrolysis is slow. The gelatinized sugarcane starch was quickly hydrolyzed by -amylase from Bacillus licheniformis (Termamyl), Bacillu subtilis (HT1000), and Aspergillus oryzae. To quickly remove the starch, starch gelatinization by heating preferentially up to $80^{\circ} \mathrm{C}$ was necessary. The authors suggested that the bacterial $\alpha$-amylase can be added before heating and then heated to a temperature range of $80-90^{\circ} \mathrm{C}$ for 30 minutes. The bacterial $\alpha$-amylase hydrolyzed the starch in dextrin and 1-7 polymerization degree oligosaccharides, and it was also suitable for sugarcane starch removal and crystalline sucrosee production.

Figure 13 illustrates the reducing sugars produced in the waxy rice, potato, cassava, waxy maize, and sugarcane starch hydrolysis by the a-amylase from Aspergillus oryzae. The sugarcane starch was hydrolyzed by the $\alpha$-amylase from Aspergillus oryzae in a procedure similar to that of the tested starches. The formation of reducing sugars glucose and maltose and a small formation of maltotriose and other oligosaccarides were also observed.

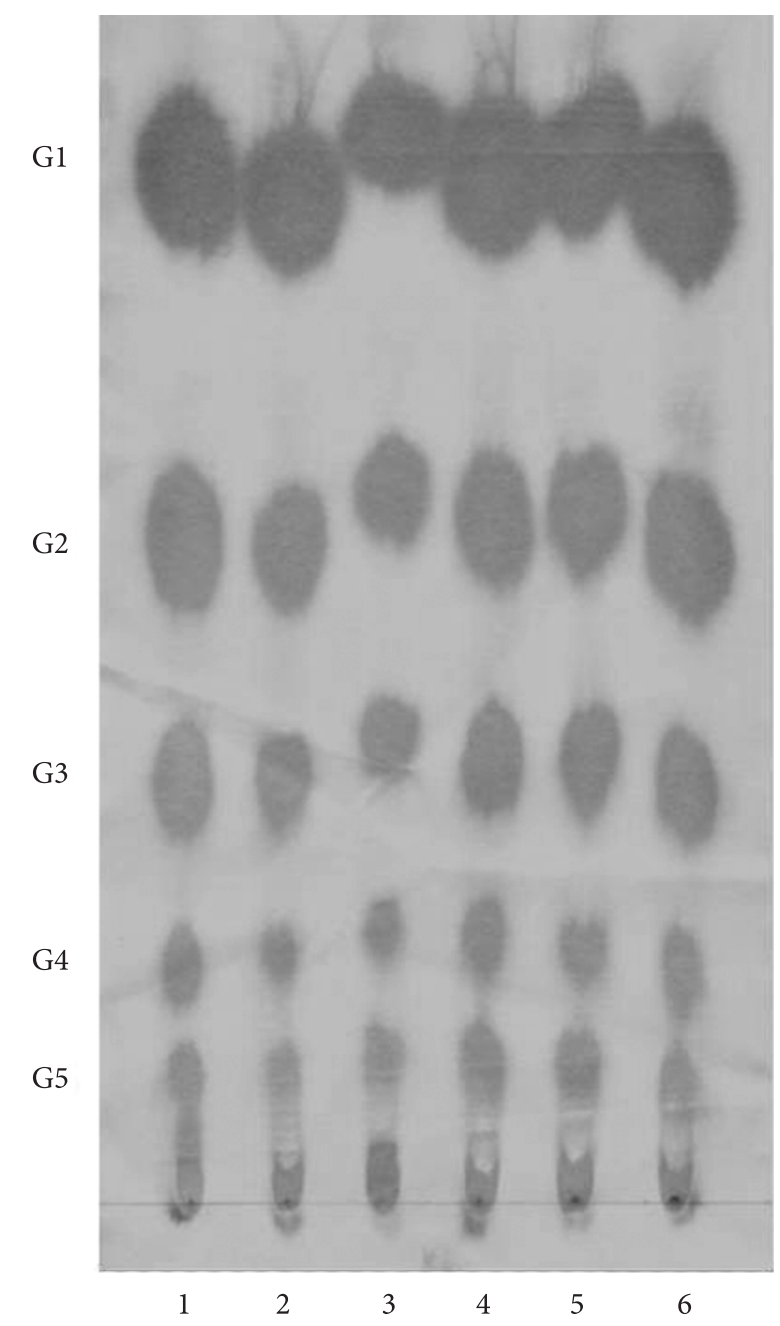

Figure 12. Reducing sugars formed after waxy rice, potato, cassava, waxy maize and sugarcane starch hydrolysis by $\alpha$-amylase from B. subtilis. 


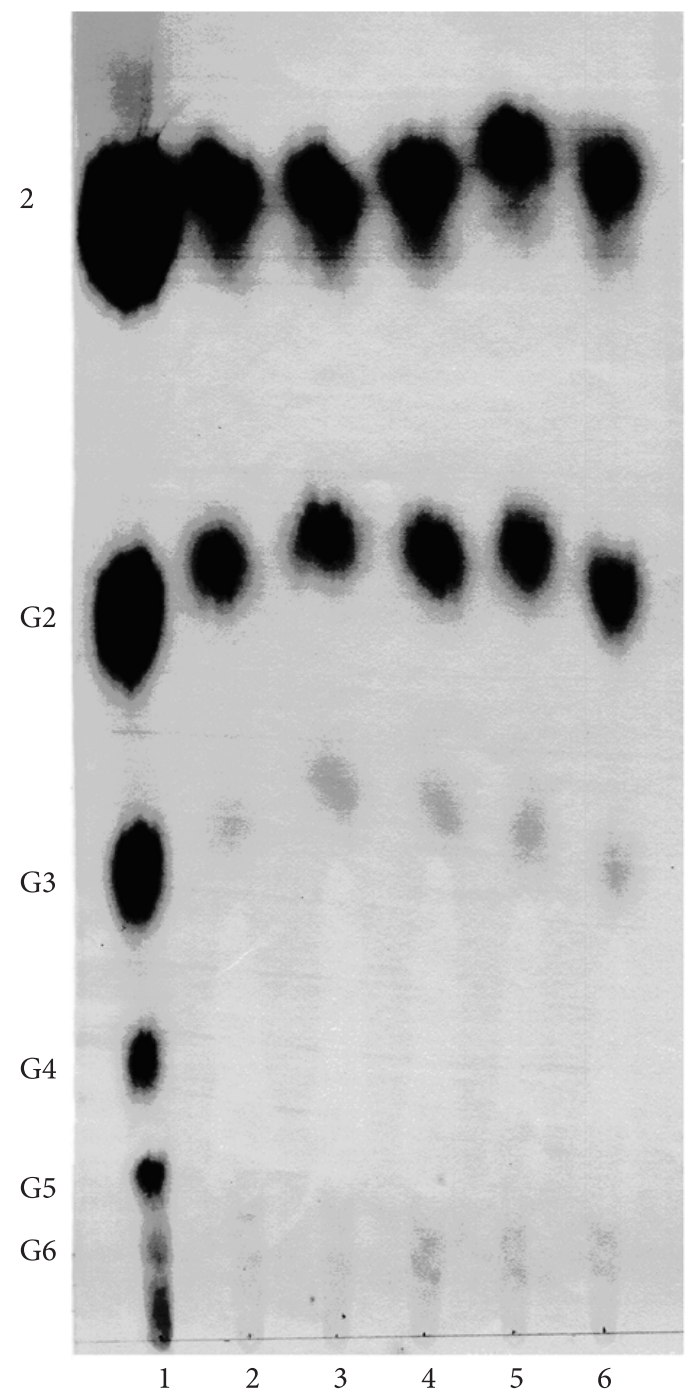

Figure 13. Reducing sugars formed after waxy rice, potato, cassava, waxy maize and sugarcane starch hydrolysis by a-amylase from Aspergillus oryzae.

The a-amylase from Aspergillus oryzae hydrolyzes the a-1,4 glycosidic bonds of starch randomly liberating a large amount of glucose and maltose. Such enzyme is thermosensitive, and it is used in bread making for starch hydrolysis and fermentable sugars glucose and maltose production. Differently from the bacterial $\alpha$-amylase, the fungal $\alpha$-amylase is disabled in temperatures of $70^{\circ} \mathrm{C}$ avoiding the extensive starch hydrolysis during the bread baking stage.

Park, Martens and Sato (1985) verified that the fungal a-amylase hydrolyzed the sugarcane starch, mostly producing maltose and a small amount of glucose and maltotriose. The authors verified that since the enzymatic preparation of fungal $\alpha$-amylase contain invertase such preparation would be suitable for the fermentation of whole sugarcane juice.

\section{Conclusions}

The determination of starch in sugarcane may be performed using potato starch or sugarcane starch as standard. The sugarcane starch determination method adopted by the CTC (Copersucar Technology Center) in which the standard curve is prepared with potato starch, is adequate since after the statistic analysis with the Minitab version 14 software through the Tukey test at $95 \%$ significance level, no difference was verified among sugarcane juice starch content values determined for each sugarcane variety with potato and sugarcane starch standard curve.

RB86-7515 and SO83-2847 sugarcane varieties showed respectively higher and lower average starch content $\left(2581 \mathrm{mg} / \mathrm{kg} \%{ }^{\circ}\right.$ Brix and $1658 \mathrm{mg} / \mathrm{kg} . \%{ }^{\circ}$ Brix) throughout the May to November 2007 crop among all the sugarcane varieties studied.

Sugarcane starch granules are spherical, present a size of about 1-3 $\mu \mathrm{m}$, and are about 5 times smaller than the cassava starch and 5-20 times smaller than the potato starch granules. In the study of membrane filterability, it was observed that fractions smaller than $0,2 \mu \mathrm{m}$ and bigger than $5,0 \mu \mathrm{m}$ are found in the gelatinized sugarcane starch suspension. Sugarcane starch gelatinization temperature ranged between $70-75^{\circ} \mathrm{C}$.

Sugarcane susceptibility to the debranching amylolytic pullulanase enzyme was similar to that of waxy maize and waxy rice starch, which contain high amylopectin content.

Gelatinized sugarcane starch presented higher susceptibility to glucoamylase enzyme than in its in natura state. In natura sugarcane starch showed higher susceptibility to glucoamylase than that of waxy maize (high amylopectin content), potato, and cassava starch, and the gelatinized sugarcane starch presented higher susceptibility to glucoamylase than that of gelatinized waxy rice, potato, cassava, and waxy maize starch.

The sugarcane starch susceptibility to commercial $\alpha$-amylase from Bacillus licheniformis, $\alpha$-amylase from Bacillus subtilis and a-amylase from Aspergillus oryzae was similar to that of waxy rice, potato, cassava, and maize starch.

\section{Acknowledgements}

The authors are grateful to the financial support provided by FAPESP to FURLAN sugar mill for the supply of sugarcane juice samples and to Mrs. Maria Madalena Mangue Esquiaveto and Mr. Danilo Tostes, from Copersucar, for the technical support.

\section{References}

ABDULLAH, M.; FRENCH, D. Substrate specificity of pullulanase. Archives of Biochemistry and Biophysics, v. 137, p. 483-493, 1970. http://dx.doi.org/10.1016/0003-9861(70)90466-2

ANYANGWA, E. M.; KAPSEU, C. E.; MUSONGE, P. The effect and removal of starch the sugar refining industry. International Sugar Journal, v. 95, p. 210-213, 1993.

ARCHIBALD, A. R. et al. $\alpha-1,4$ - Glucosans. Part XI: The Absorption Spectra of Glycogen and Amylopectin - Iodine Complexes. Journal of the Chemical Society, p. 1183-1190, 1988

ARIAS, L. V. B. Fécula de mandioca e polvilho azedo para fabricação de pão de queijo. In: PIZZINATO, A.; ORMESE, R. C. S. S. Seminário Pão de Queijo: Instituto de Tecnologia de Alimentos, 2000. p. 1-14. 
BEMILLER, J. N.; WHISTLER, R. L. Food Chemistry. Edited by Owen R. Fennema. 3th ed. New York: Marcel Dekker, 1996. p. 158-221.

BOYES, P. N. Quantitative determination of some non-sugars and partial removal of one in particular- starch. Proceedings of South African Sugar Technologists' Association, v. 32, p. 37-43, 1958.

CUDDIHY, J. A.; PORRO, M. E.; RAUH, J. S. The presence of total polysaccharides in sugar production and methods for reducing their negative effects. Journal of American society of Sugarcane Technologists, v. 21, p. 73-91, 2001.

CUMMINS, A. B.; WEYMOUTH, L. E. Filtration of sugar solutions: Some factors determined by laboratory test procedures. Industrial and Engineering Chemistry, v. 34, p. 392-398, 1942.

EGGLESTON, G; LEGENDRE, B.; TEW, T. Indicators of freezedamaged sugarcane varieties which can predict processing problems. Food Chemistry, v. 87, n. 1, p. 119-133, 2004.

GODSHALL, M. A. et al. Starch, polysaccharide and proanthocyanidin in Louisiana sugarcane varieties. International Sugar Journal, v. 98, p. 144-148, 1996.

IMRIE, F. K. E.; TILBURY, R. H. Polysaccharides in sugar cane and its products. Sugar Technology Reviews, v. 1, p. 291-361, 1972.

KAMPEN, W. H. The action of alpha-amylase on sugarcane starch. Lousiana. Disponível em: <www.midlandresearchlabsinc.com>. Acesso em: 15 ago. 2006.

PARK, Y. K.; MARTENS, I. S. H.; SATO, H. H. Enzymatic removal of starch from sugarcane during sugarcane processing. Process Biochemistry, v. 20, p. 57-59, 1985.
RÍAZ, M. et al. Kinetic and termodynamic properties of novel glucoamylase from Humicola sp. Enzyme and Microbial Technology, v. 41, p. 558-564, 2007.

SATO, H. H. Produção, purificação e estudos das propriedades da isoamilase de Flavobacterium sp. 1979. Dissertação ( Mestrado em Ciencia de Alimentos)-Faculdade de Engenharia de Alimentos, Universidade Estadual de Campinas, Campinas, 1979.

SATO, H. H. Estudo das Características bioquímicas da pululanase de Klebsiella sp. e sua aplicação. 1991. Tese (Doutorado em Ciencia de Alimentos)-Faculdade de Engenharia de Alimentos, Universidade Estadual de Campinas, Campinas, 1991.

SOMOGYI, M. A. A new reagent for the determination of sugars. Journal of Biology and Chemistry, v. 160, p. 61-68, 1945.

STEVENSON, J. C.; WHAYMAN, E. Cane Starch -Part I-Isolation and iodine affinity. International Sugar Journal, p. 44-46, 1976.

TREVELYAN, W. E.; PROCTER, D. P.; HARRISON, J. G. Detection of sugars on paper chromatograms. Nature, v. 166, p. 444-445, 1950.

VIGNES, E. C. Notes on Cane Starch and its Determinations. In: CONGRESS OF INTERNATIONAL SOCIETY OF SUGAR CANE TECHNOLOGISTS - ISSCT, 15., 1974, Hawai. Proceedings... ISSCT, 1974. v. 3, p. 1288-1295.

WANKHEDE, D. B.; RHATEKE, R. S. Synergistic digestibility of several native starches by amylolitic enzymes. Starch/Starke, v. 39, n. 9, p. 309-312, 1982. http://dx.doi.org/10.1002/star.19820340908

WHAYMAN, E.; WILLERSDORF, A. L. Cane Starch - Part II - Starch components and their iodine complex spectra. International Sugar Journal, p. 67-68, 1976. 